Article

\title{
An Evaluation of the Microstructure of High-Aluminum Cast Iron in Terms of the Replacement of Aluminum Carbide with Titanium Carbide or Tungsten Carbide
}

\author{
Robert Gilewski ${ }^{1,2}$, Dariusz Kopyciński ${ }^{1, * \mathbb{D}}$, Edward Guzik ${ }^{1}$ and Andrzej Szczęsny ${ }^{1}$ \\ 1 Faculty of Foundry Engineering, AGH University of Science and Technology, Al. A. Mickiewicza 30, \\ 30-059 Kraków, Poland; gilbert-rg@o2.pl (R.G.); guz@agh.edu.pl (E.G.); ascn@agh.edu.pl (A.S.) \\ 2 Electrical School Complex No. 1, ul. Kamienskiego 49, 30-644 Krakow, Poland \\ * Correspondence: djk@agh.edu.pl
}

check for updates

Citation: Gilewski, R.; Kopyciński, D.; Guzik, E.; Szczęsny, A. An Evaluation of the Microstructure of High-Aluminum Cast Iron in Terms of the Replacement of Aluminum Carbide with Titanium Carbide or Tungsten Carbide. Appl. Sci. 2021, 11, 9527. https://doi.org/10.3390/ app11209527

Academic Editor: Artur Bobrowski

Received: 2 September 2021

Accepted: 7 October 2021

Published: 13 October 2021

Publisher's Note: MDPI stays neutral with regard to jurisdictional claims in published maps and institutional affiliations.

Copyright: (c) 2021 by the authors. Licensee MDPI, Basel, Switzerland. This article is an open access article distributed under the terms and conditions of the Creative Commons Attribution (CC BY) license (https:/ / creativecommons.org/licenses/by/ $4.0 /)$.

\begin{abstract}
One of the problems with recycling is that of widespread contaminated steel scrap with an unwanted aluminum addition. In this paper, we will present a specific solution to this problem. The implementation of high-aluminum cast iron production has been considered. This cast iron is a cheap material resistant to high temperatures; additionally, it has increased abrasion resistance. Despite the above-mentioned advantages, high-aluminum cast iron has not been widely used in the industry so far, due to the difficulties encountered during machining and the occurrence of the phenomenon of spontaneous disintegration. The paper presents a method for replacing aluminum carbide with titanium carbide or tungsten carbide. This research shows that the carbide replacement procedure is sufficient in stopping the phenomenon of self-disintegration of a casting made of high-aluminum cast iron. Moreover, a new material was obtained, i.e., high-aluminum cast iron with precipitates of hard tungsten carbide and flake graphite. When considering the abrasive resistance of this material, flake graphite can be treated as the natural lubricant phase and tungsten carbide precipitation, as the hardening phase.
\end{abstract}

Keywords: high-aluminum cast iron; $\mathrm{Al}_{4} \mathrm{C}_{3}$ carbide; titanium carbide; tungsten carbide

\section{Introduction}

Aluminum, depending on its content in cast iron, promotes or prevents graphitization. It can act as a graphitizer or stabilizer depending on the quantity in which it is present in cast iron. Therefore, taking into account the widespread presence of aluminum in iron or steel scrap, it is possible to use this contaminated scrap for the production of high-aluminum cast iron [1-4], which should be used in the construction of machine elements. Fe-C-Al alloys, which contain up to $30 \%$ mass $\mathrm{Al}$, show two characteristic ranges of graphitization. The first one includes alloys with up to $8 \mathrm{wt}$. Al, while the second alloys with a content of 18-26 mass \% Al. With a content of 9-16 mass \% Al and with a content exceeding 26 mass \% with $\mathrm{Al}$ in cast iron, carbon is found only in the bound form [5-8]. Figure 1 shows the relation between the aluminum content in cast iron and the form of carbon occurrence [9] and several areas can be defined, including [\% mass]:

Area I-When a small amount of aluminum is introduced into cast iron, in the order of $1.5-2.5 \%$, it shows a ferritic-pearlitic structure. A further increase of the aluminum content to $3.6 \%$ increases the proportion of ferrite in the matrix. Increasing the aluminum content to $3.6 \%$ causes the formation of thick particles of graphite. The addition of aluminum in this area causes, in principle, structural changes analogous to those that occur with the addition of silicon contents; 


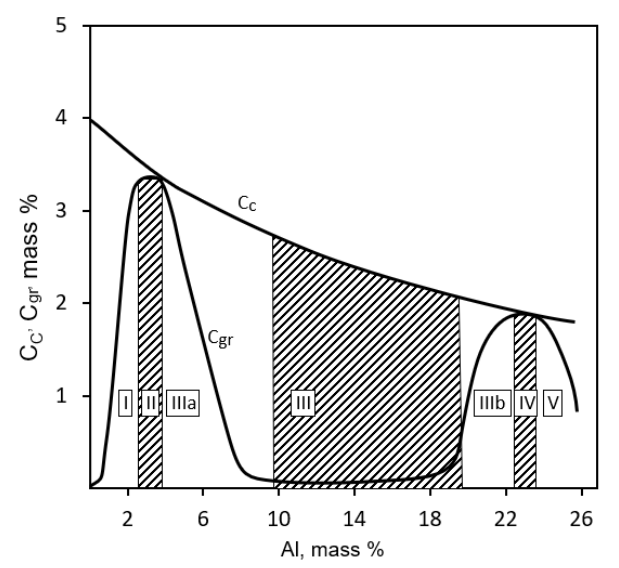

Figure 1. Influence of $\mathrm{Al}$ on the graphitization of cast iron.

Area II-It corresponds to cast iron with an aluminum content of 3.2-3.8\%. The structure is ferritic with the most extensive precipitates of graphite;

Area IIIa-Eutectoid appears in this range; ferrite $+\varepsilon$. It is a perlite-like structural mixture;

Area III-In this area $(9.7-11.5 \% \mathrm{Al})$, there is no longer any graphite. The structure of this area does not change with the increased cooling rate of the castings; Area IIIb-The structure of this area $(19.0-23.0 \% \mathrm{Al})$ consists of coarse particles of graphite, primary particles of phase $\varepsilon$ and ferrite. As is the case of the structure in area IIIa, the structure of area IIIb changes during the different cooling rates of the alloys.

Area IV-In this area $(22.7-23.5 \% \mathrm{Al})$, similarly to area II, there is a structure containing ferrite and graphite.

Area V-This area includes cast iron with a content of $24.0-30.0 \% \mathrm{Al}$. and contains: graphite, ferrite, and aluminum carbides; however, with increased aluminum content, the graphite content decreases until it disappears. Cast iron with about $30 \% \mathrm{Al}$ is a special purpose cast iron. It shows very good resistance to an oxidizing atmosphere at a high temperature, but castings made of this iron tend to break down during operation, as shown in Figure 1.

In general, high-alumina cast iron is very similar to the well-known materials from the iron aluminides group [10-13]. Increasing the content of aluminum in cast iron reduces its density and improves resistance to oxidation. For this purpose, a metal charge contaminated with $\mathrm{Al}$ can be used [1-4]. High-aluminum cast iron with higher aluminum content belongs to the group of so-called white cast iron. It turns out that the barrier in the field of application of this material is the concentration of carbon in cast iron and the formation of hygroscopic $\mathrm{Al}_{4} \mathrm{C}_{3}$ carbide from aluminum. The property of this carbide and its morphology in the form of fibers and plates with a thickness of several micrometers cause that, the reaction to water in the form of liquid or gas is intensive and leads to the destruction of the material, the so-called "self-decay" as a result of volume expansion, after the reaction of aluminum carbide to water particles, according to this:

$$
\begin{gathered}
\mathrm{Al}_{4} \mathrm{C}_{3}+12 \mathrm{H}_{2} \mathrm{O} \rightarrow 4 \mathrm{Al}(\mathrm{OH})_{3}+3 \mathrm{CH}_{4} \uparrow \\
4 \mathrm{Al}(\mathrm{OH})_{3} \rightarrow 2 \mathrm{Al}_{2} \mathrm{O}_{3}+6 \mathrm{H}_{2} \mathrm{O}
\end{gathered}
$$

The reason for this is the appearance of the $\mathrm{Al}(\mathrm{OH})_{3}$ compound, the volume of which is about 2.5 times greater than the specific volume of $\mathrm{Al}_{4} \mathrm{C}_{3}$ carbides that react with water. This phenomenon causes high stress and breaks the continuity of the alloy matrix.

\section{The Triple Phase Equilibrium System of Fe-Al-C Alloys Developed in the Thermo-Calc Program}

The Thermo-Calc program was used to plot the triple system of the Fe-Al-C alloy that can provide relevant information. These graphs were made for various temperature 
values. They are presented in Figure 2. It is worth noting that at a temperature above $800{ }^{\circ} \mathrm{C}$, it is possible to separate carbon in the form of graphite, starting from the carbon content of $2.5 \%$.

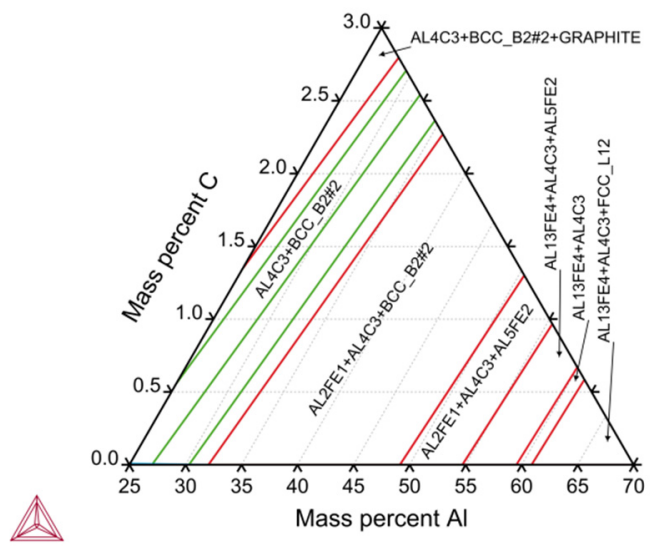

(a)

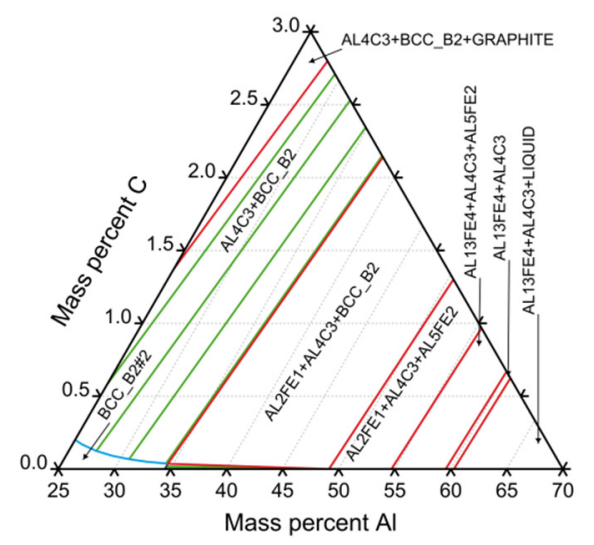

(c)

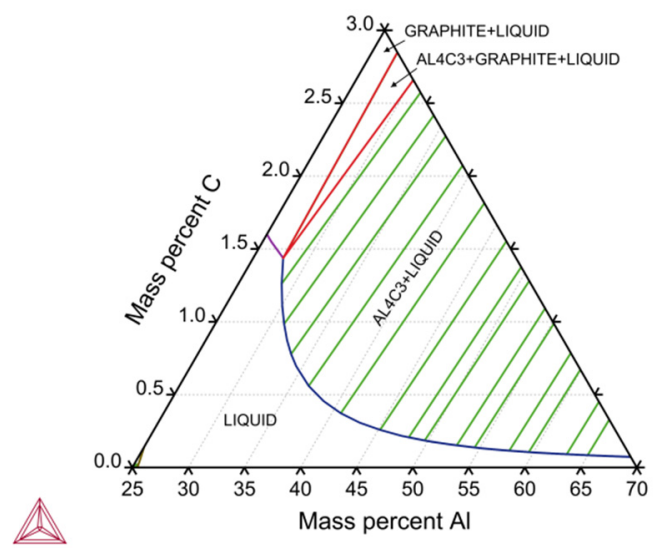

(e)

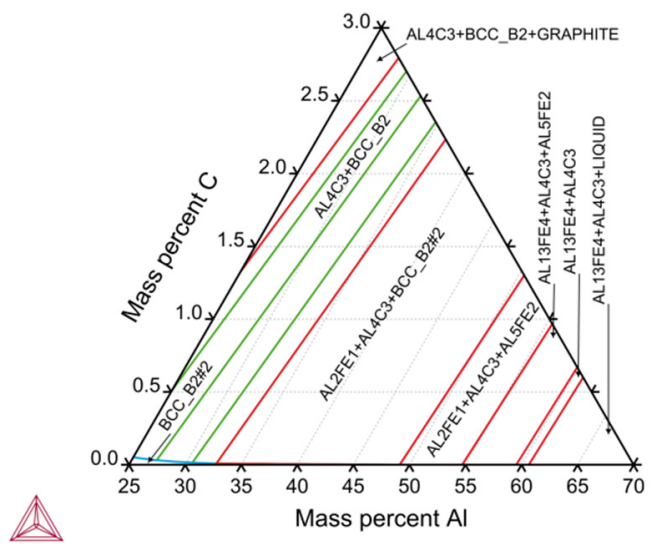

(b)

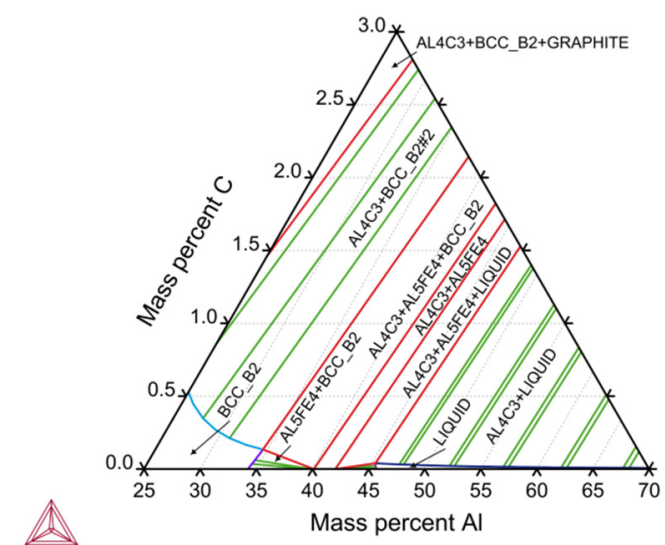

(d)

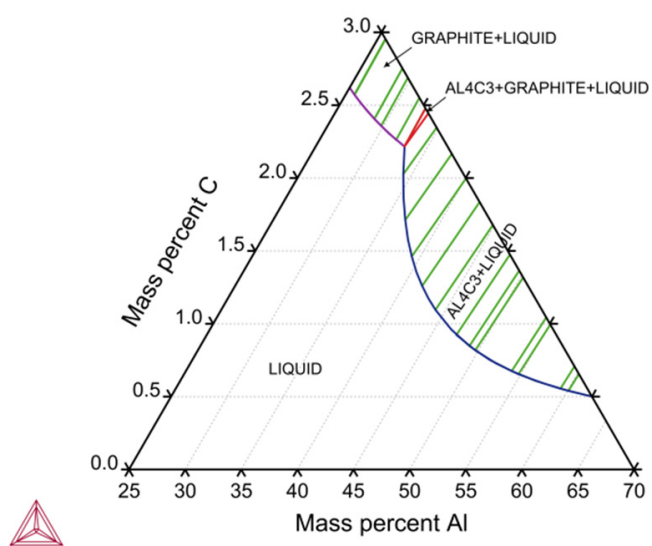

(f)

Figure 2. Phase equilibrium system of Al-Fe-C alloys obtained in the Thermo-Calc program for the following temperatures: $600{ }^{\circ} \mathrm{C}(\mathbf{a}), 800{ }^{\circ} \mathrm{C}(\mathbf{b}), 1000{ }^{\circ} \mathrm{C}(\mathbf{c}), 1200{ }^{\circ} \mathrm{C}(\mathbf{d}), 1400{ }^{\circ} \mathrm{C}(\mathbf{e}), 1600{ }^{\circ} \mathrm{C}(\mathbf{f})$. Possible is to separate carbon in the form of graphite, starting from the carbon content of $2.5 \%(\mathbf{b}-\mathbf{f})$. 


\section{Methodology}

The PIT 30 medium frequency induction furnace with a thyristor inverter and a brick crucible, with a charge capacity of $30 \mathrm{~kg}$ was used to perform the melts. The melted alloy was superheated to $1540{ }^{\circ} \mathrm{C}$ and then cast-iron samples were cast at $1420^{\circ} \mathrm{C}$. A bentonite mass was used to make the molds, which is made of quartz sand-matrix, bentonite-binder, water, and coal dust as an additive. The molds were dried in a core and mold dryer at a temperature of $200{ }^{\circ} \mathrm{C}$. In order to carry out the tests, three rollers with a diameter of $30 \mathrm{~mm}$ and a length of $260 \mathrm{~mm}$ were cast simultaneously in one mold. The so-called grate bars for a power boiler were also cast.

The microscopic observations of the samples were carried out on the LEICA optical microscope, coupled with a computer, according to the Leica $\mathrm{Q}$ Win program. The assessment of the SEM microstructure and the analysis of the phase composition in the structure of the investigated cast iron and the analysis of the chemical composition were carried out on the JEOL 500LV SEM scanning microscope with an X-ray microanalysis (EDS) attachment.

\section{Assessment of the Structure of Cast Iron Prone to Spontaneous Disintegration}

To determine the structure, samples were made of high-aluminum cast iron with the following chemical composition [mass $\%$ ]: $34.7 \% \mathrm{Al}, 0.91 \% \mathrm{C}, 0.29 \% \mathrm{Si}, 0.25 \% \mathrm{Mn}$. The microstructure of the obtained cast iron is shown in Figure 3 and was characterized by a structure composed of wall aluminum carbides and a ferritic matrix.

Figure $3 \mathrm{a}, \mathrm{b}$ shows matrix cracks along the carbide plates, suggesting that the mechanical strength of carbide is greater than the metal matrix. During the crystallization of the alloy and its free contraction, aluminum carbide can resist the metal matrix, causing mechanical stress. The largest of them are accumulated on the periphery of the carbide, causing the notch effect, and hence a straight path to the destruction of the metal matrix. In an extreme case, when the bending strength $R_{g}$ of the carbide is exceeded, it also undergoes destruction, as shown in Figure 4. During the resulting decohesion of the metal matrix and the carbide, a micro-gap is formed, into which water vapor in the air can diffuse without any obstacles, thus reacting with the aluminum carbide. Subsequently, the $\mathrm{Al}_{4} \mathrm{C}_{3}$ carbide begins to increase its volume, causing destruction of the casting in its entire volume, not only in the outer layers. After microcracks appear, water vapor can get into the internal structures of the casting faster and as a secondary factor, it can destroy it quicker.

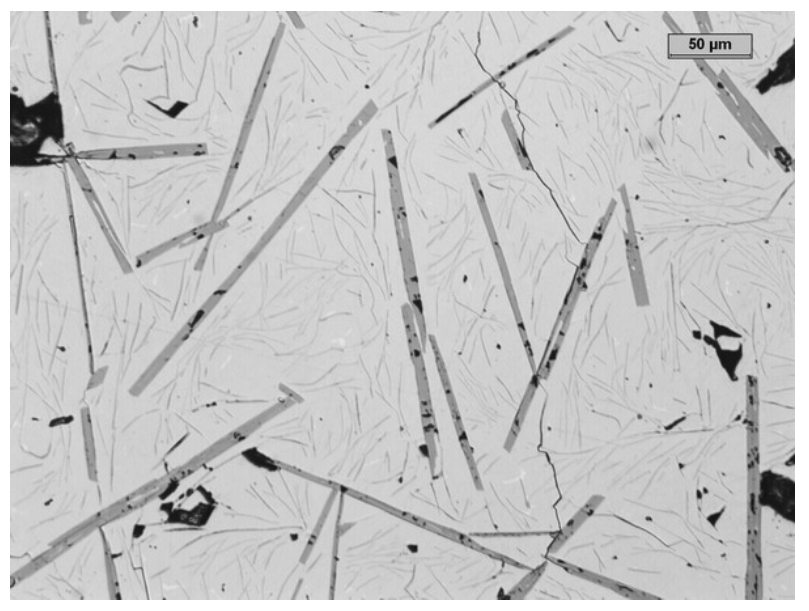

(a)

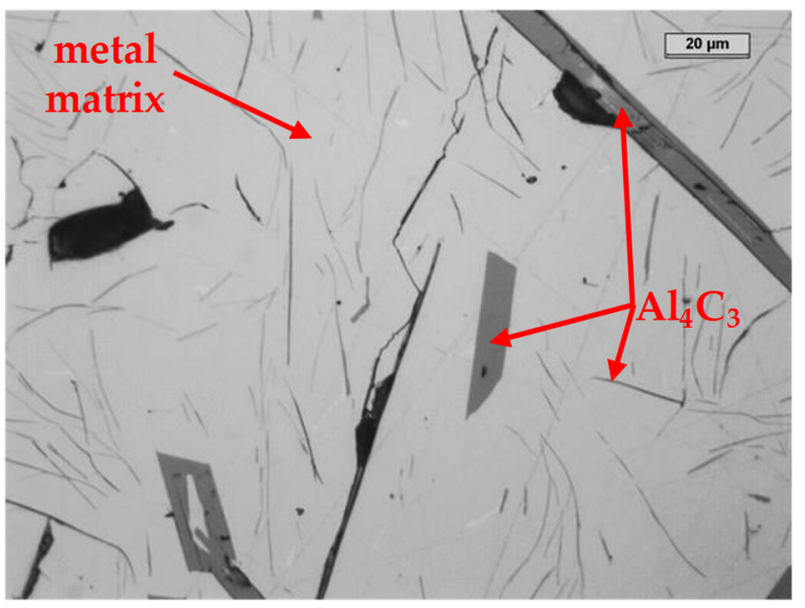

(b)

Figure 3. Microstructure (LM) of the specimens of the reference sample of high-aluminum cast iron, with visible fractures of the metal matrix $(\mathbf{a}, \mathbf{b})$. 


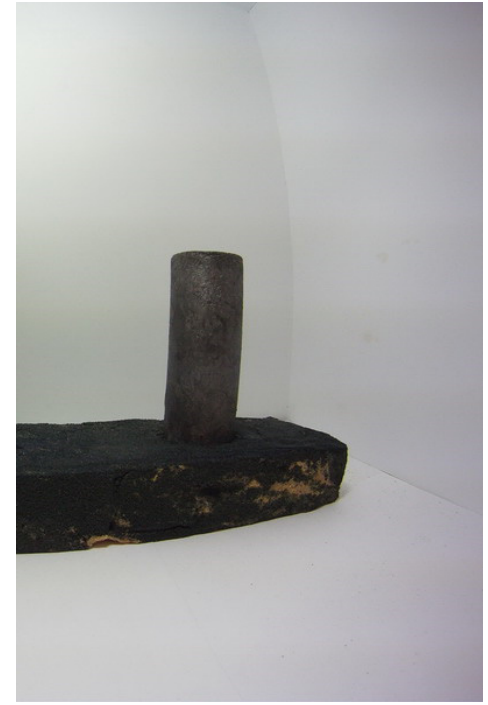

(1)

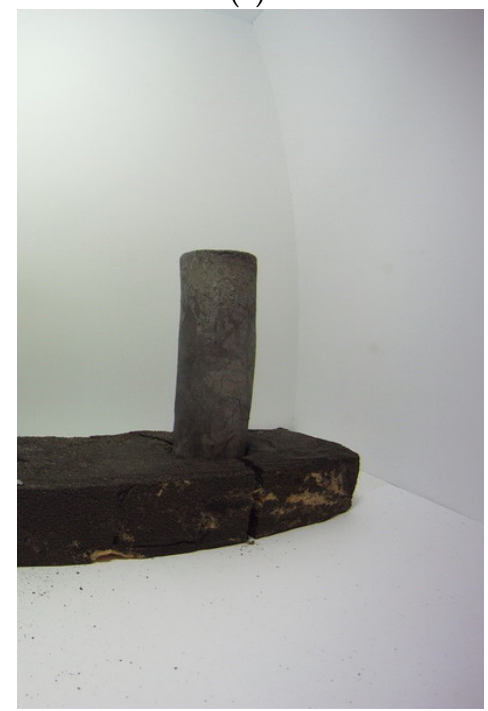

(11)

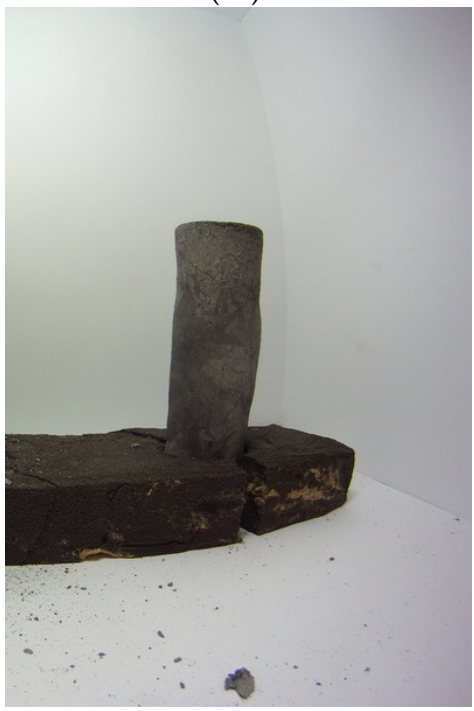

(18)

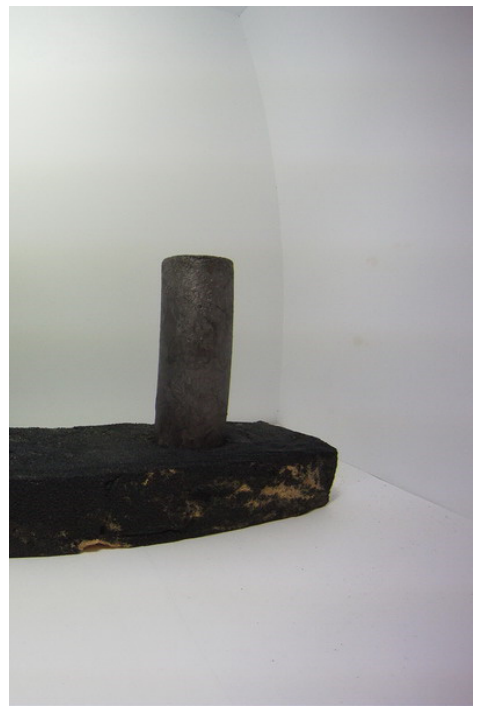

(3)

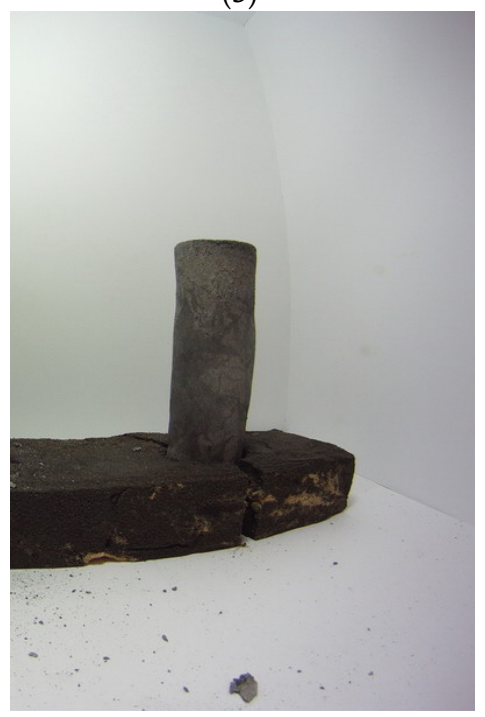

(15)

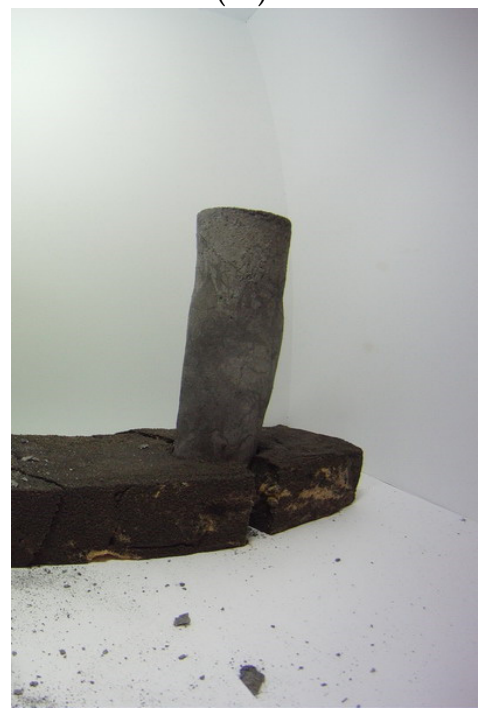

(20)

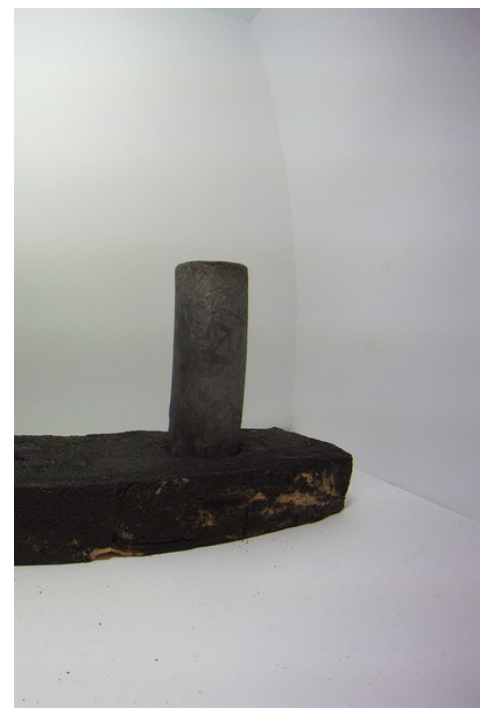

(7)

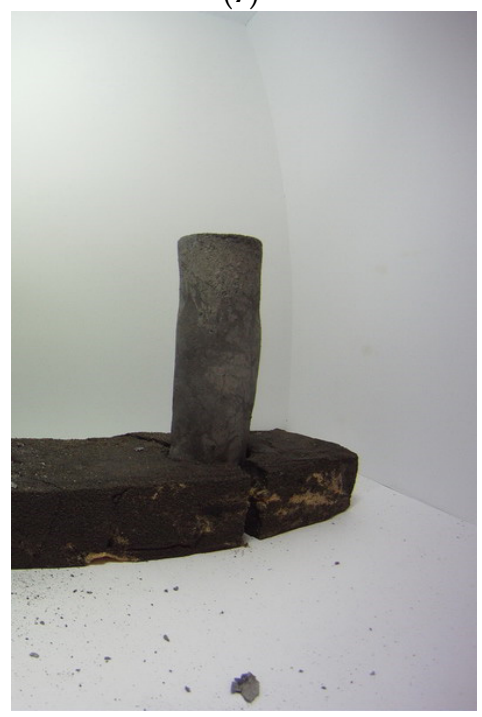

(17)

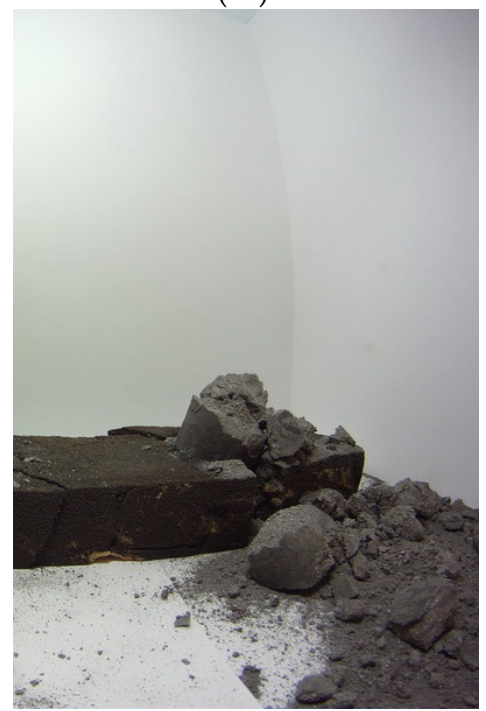

(21)

Figure 4. Spontaneous decay of high-aluminum cast iron; the number underneath of the photo shows the day the photo was taken. 
Over a period of 21 days, the sample disintegrated as shown in the photos in Figure 4. When analyzing the posted photos, it can be quickly noticed that the tested sample swells and increases its volume over time. After analyzing the above observation, it seems advisable to replace the $\mathrm{Al}_{4} \mathrm{C}_{3}$ carbide with another with carbide-forming elements, e.g., Ti, $\mathrm{V}, \mathrm{W}$. Such treatment may not only cause complete elimination of the $\mathrm{Al}_{4} \mathrm{C}_{3}$ carbide but also change the shape of the carbide. The compact shape of the new carbide, e.g., TiC, VC, WC, will not cause excessive stress during free shrinkage, contributing to the durability of the casting. This paper presents the effect of titanium and tungsten on the change of the microstructure, which includes precipitations of titanium carbide or flake graphite and various precipitations of tungsten carbide. In addition, it has been proven that castings can be produced from this material.

\section{An Example of Producing a High-Aluminum Cast Iron}

The study assumes the development of the simplest possible method of obtaining high-aluminum cast iron, which would not be prone to "self-disintegration". In earlier studies, a method of replacing aluminum carbide with another type of carbide, e.g., TiC, was developed. Figure 5 shows the changes in the microstructure that will be visible when we introduce the appropriate titanium content into the cast iron. The research shows that the degree of replacement of aluminum carbides with titanium carbides depends on the content of the introduced titanium (according to Equation (3)).

$$
\mathrm{Ti}+\mathrm{C} \rightarrow \mathrm{TiC}
$$

Reaction (3) shows that $1 \mathrm{~g}$ of titanium binds $0.25 \mathrm{~g}$ of carbon, which gives $1.25 \mathrm{~g}$ of $\mathrm{TiC}$ carbide. For the casting conditions, the $\Delta \mathrm{G}$ free energy of $\mathrm{Al}_{4} \mathrm{C}_{3}$ carbide reaction formation will be $-96 \mathrm{~kJ}$. On the other hand, the free energy of $\Delta \mathrm{G}^{0}$ reaction formation of TiC carbide is $-166 \mathrm{~kJ}$. Thus, with the minimum amount of titanium needed to replace the $\mathrm{Al}_{4} \mathrm{C}_{3}$ carbide, TiC carbide will appear in the structure.

An experiment with the use of titanium as a carbide-forming element ended the initial period of searching for a method blocking the "self-disintegration" of a casting made of high-aluminum cast iron. For example, an industrial application was tested in the form of casting the so-called grate bars for a power boiler.

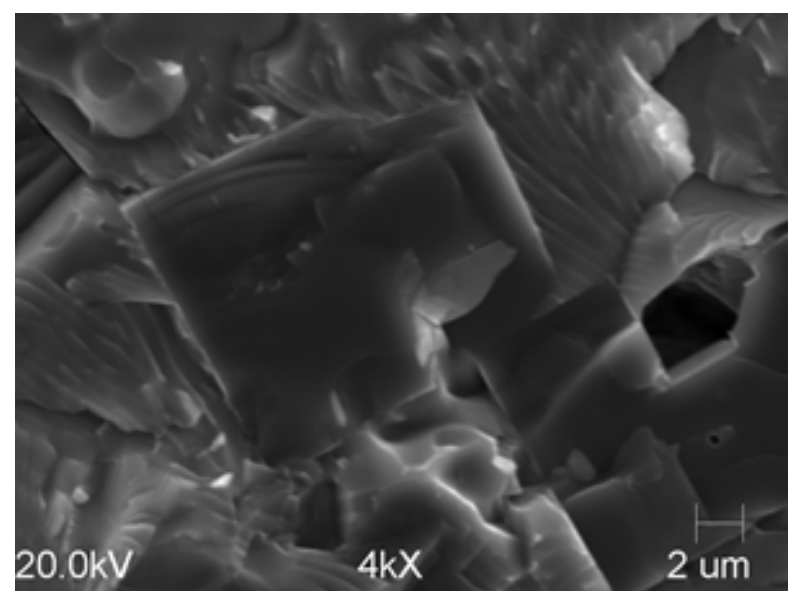

(a)

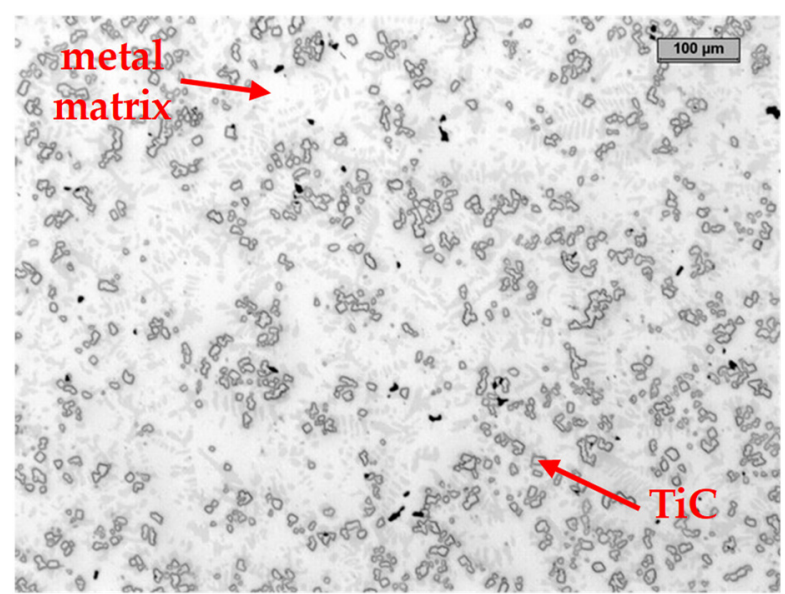

(b)

Figure 5. Precipitates of titanium carbides in SEM microstructure (a) and microstructure (LM) of high-aluminum cast iron with precipitates of titanium carbides $(\mathbf{b})$.

The furnaces of power boilers have belt grates with fully mechanized feeding and cleaning. The grate surface is made of separate cast-iron grates. This method of construction ensures that the drive chain articulated links are remote from the "heat", and the gratings can be easily replaced. The fuel slides automatically from the coal basket onto the grate 
deck and moves along with it through the furnace. The grate bars are rotatably mounted in the pins in the so-called "Holders" attached to the grate chains. In the upper run, the grate strips overlap, while in the lower run they fall vertically, which allows them to clean from slag and ash. The mass of the burned fuel can be adjusted with the grate advance speed (max. $0.8 \mathrm{~m} / \mathrm{min}$.) and the thickness of the fuel layer, which (depending on the type of coal) is $50-150 \mathrm{~mm}$. The grates in power boilers operate in very harmful conditions of use. The most unfavorable is the increased operating temperature, sometimes reaching $800{ }^{\circ} \mathrm{C}$, and in some cases, e.g., in the event of a blower failure, much higher. The method of feeding the boiler by pouring solid fuel (coal), the hardness of which will affect the accelerated wear ("abrasion") of the grate bars, is also important. The chemical effect of sulfur contained in coal (max. $0.6 \%$ ) on the grate material also has a considerable influence. For research purposes, two castings were made (Figure $6 a, b$ ). The first (reference) with the chemical composition presented in Table 1 and the second one in Table 2. After about 14 days, signs of spontaneous disintegration of the first grate were noticed (Figure $6 \mathrm{c}$ ), while the second grate, containing titanium carbide precipitates, Figure $6 \mathrm{~d}$, functioned for five years; it did not disintegrate, maintaining its glossy surface.

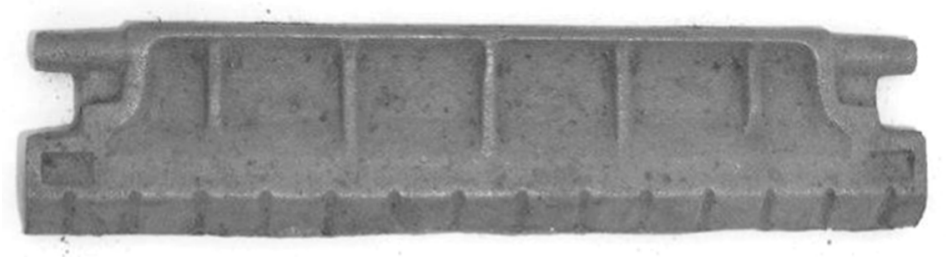

(a)

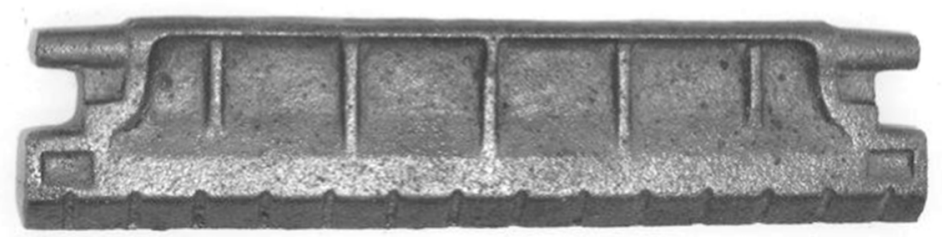

(b)

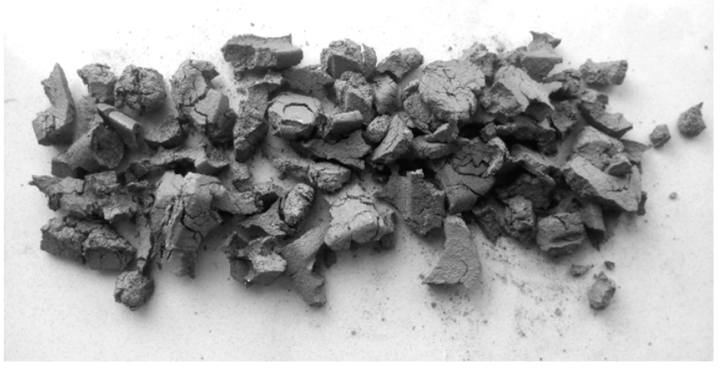

(c)

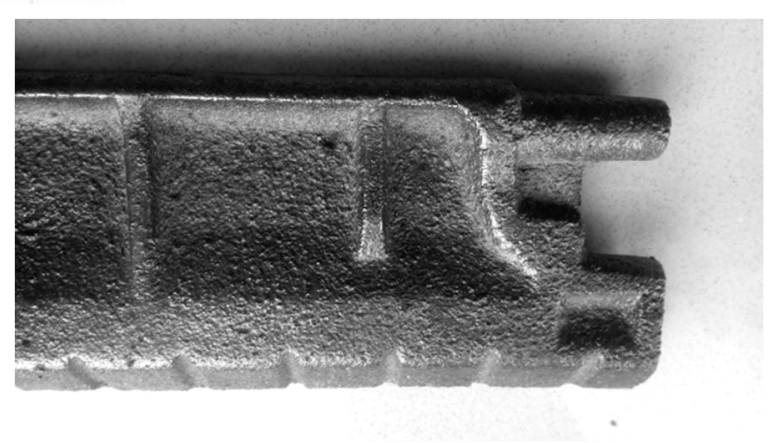

(d)

Figure 6. Photographs of high-aluminum cast iron $(a, c)$ and high-aluminum cast iron castings with the addition of titanium $(\mathbf{b}, \mathbf{d})$.

Table 1. Chemical composition of the reference cast iron.

\begin{tabular}{cccccccc}
\hline Element & Al & C & Si & Mn & Ti & S & Fe \\
\hline$\%$ mass & 34.70 & 0.91 & 0.29 & 0.25 & - & 0.01 & remain \\
\hline
\end{tabular}

Table 2. Chemical composition of the investigated cast iron.

\begin{tabular}{cccccccc}
\hline Element & Al & C & Si & Mn & Ti & S & Fe \\
\hline$\%$ mass & 33.61 & 2.12 & 1.08 & 0.40 & 5.60 & 0.01 & remain \\
\hline
\end{tabular}


When developing the chemical composition of a casting, it should not be assumed that every mass of carbon in the molten alloy can be freely "exchanged" with carbideforming elements. At high carbon concentrations, casting is expected to be thixotropic in nature even in the presence of elevated temperatures in excess of $1600^{\circ} \mathrm{C}$. Therefore, it was decided to change the structure of high-aluminum cast iron with another carbide-forming element, in this case, tungsten, which was assumed to affect the strength properties of the metal matrix of the cast iron.

In addition, a comparative test was carried out in which several high-aluminum cast iron specimens were inserted into a special stand. Over a 7-month period of examination, 21,000 images were taken and the results are shown in Figure 7.

Three of the eight samples of high aluminum cast iron were not subject to the selfdestruction mechanism. First with titanium added (Ti), second with boron-modified and heat treatment [14], and the third sample represents the authors' know-how.

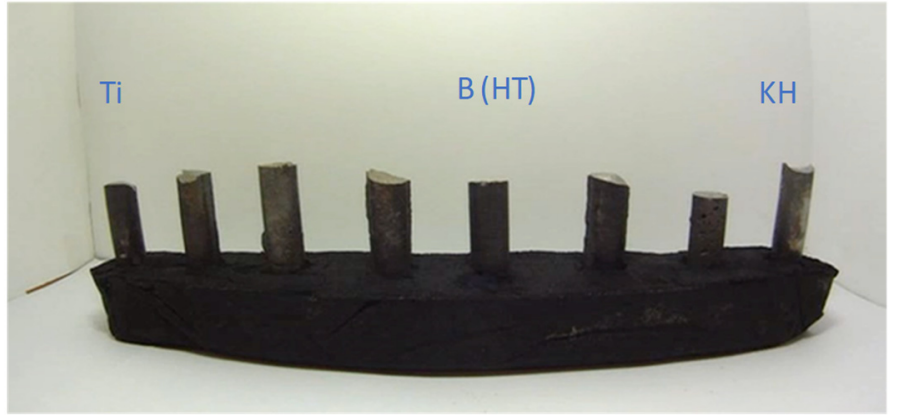

(a)

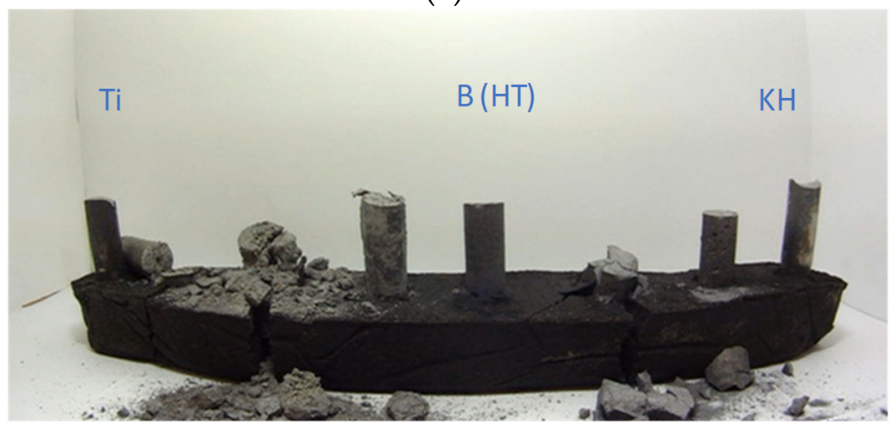

(c)

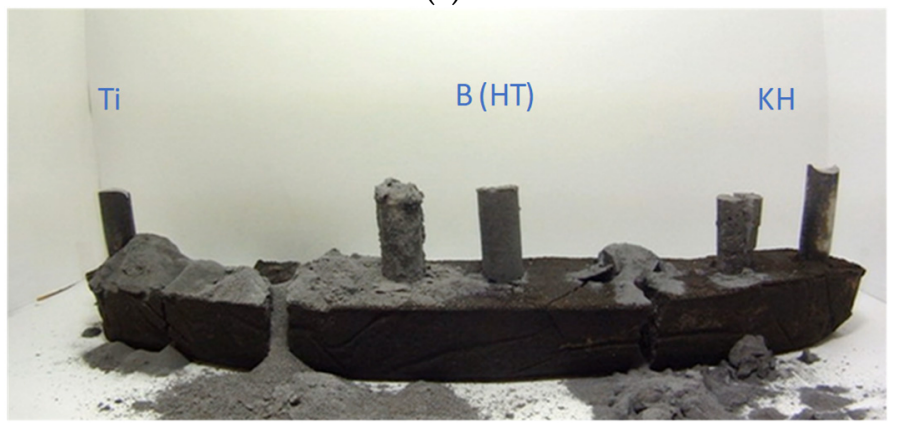

(e)

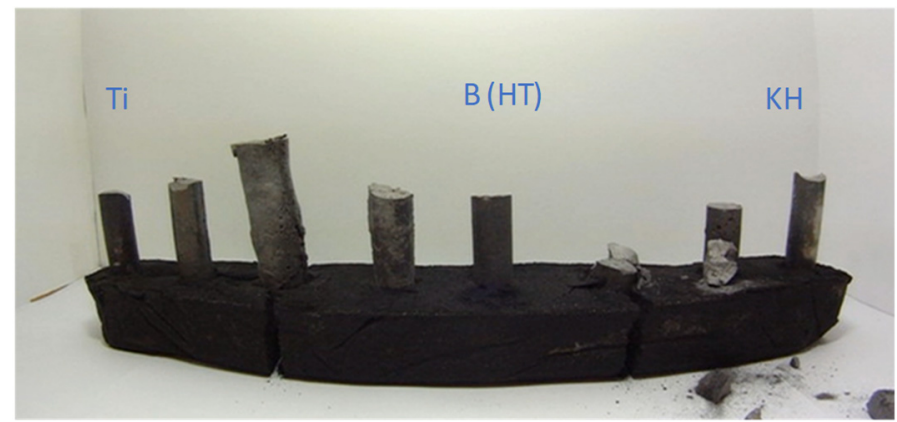

(b)

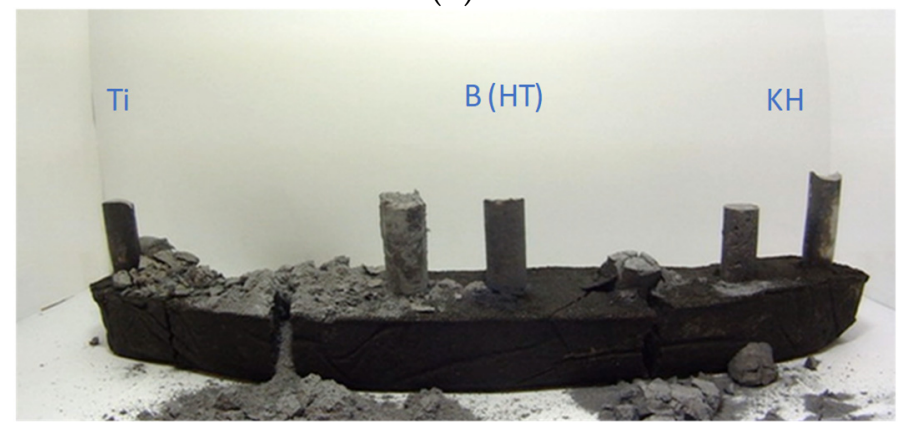

(d)

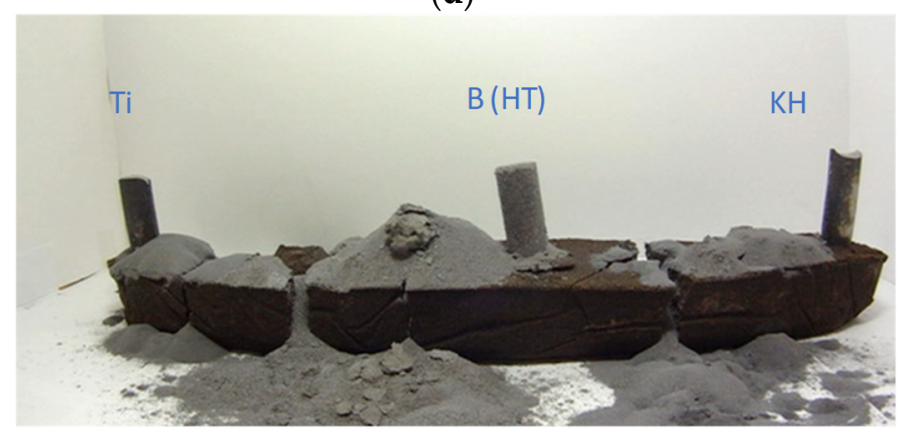

(f)

Figure 7. Self-destruction of different types of high-aluminum cast iron within 7 months after casting: Ti-titanium addition, $\mathrm{B}(\mathrm{HT})$ - boron modification and after heat treatment, $\mathrm{KH}$ - know-how of author; other samples were characterized by a variety of high-aluminum cast-iron structures consisting mainly of carbide eutectics $\mathrm{Al}_{4} \mathrm{C}_{3}$ and hypereutectic $\mathrm{Al}_{4} \mathrm{C}_{3}$ carbides. The images were taken over a period of four days (a), 40 days (b), 76 days (c), 112 days (d), 146 days (e), 184 days (f). 


\section{The Structure of Cast Iron after Introducing Tungsten and Its Resistance to Abrasive Wear}

In the case of tungsten as an alloying additive to high-aluminum cast iron, the complete substitutability of the $\mathrm{Al}_{4} \mathrm{C}_{3}$ carbide by WC carbide is uncertain. The reason is the value of the free energy $\Delta G^{0}$ of the WC carbide formation reaction, which is about $-34 \mathrm{~kJ}$ (for $\mathrm{W}_{2} \mathrm{C}$ carbide, similarly $\Delta \mathrm{G}^{0}=-35 \mathrm{~kJ}$ ). Therefore, it can be assumed that the degree of replacement of aluminum carbides with tungsten carbides does not have to depend on the content of tungsten introduced (according to Equation (4)), as it was in the case with the introduction of titanium (Equation (3)).

$$
\mathrm{W}+\mathrm{C} \rightarrow \mathrm{WC},
$$

Equation (4) shows that $1 \mathrm{~g}$ of tungsten binds $0.065 \mathrm{~g}$ of carbon, which gives $1.065 \mathrm{~g}$ of WC carbide. It is four times less than titanium. Therefore, a much larger addition of tungsten was assumed in the research. The melted alloy with the chemical composition presented in Table 3 was superheated to a temperature of $1510^{\circ} \mathrm{C}$, and then samples were poured for metallographic tests at a temperature of $1420^{\circ} \mathrm{C}$. Tungsten in the form of ferroalloy was then introduced into the thus prepared melted cast iron. The samples were cast into dried molds made of bentonite mass, from which metallographic specimens were later made. In order to obtain information on the influence of tungsten on the structure of high-aluminum cast iron, the microstructure of the samples was examined.

Table 3. Chemical composition of the investigated cast iron.

\begin{tabular}{cccccccc}
\hline Element & $\mathbf{A l}$ & $\mathbf{C}$ & $\mathbf{S i}$ & $\mathbf{M n}$ & $\mathbf{W}$ & $\mathbf{S}$ & $\mathbf{F e}$ \\
\hline$\%$ mass & 31.30 & 1.35 & 1.05 & 0.37 & 16.08 & 0.01 & remain \\
\hline
\end{tabular}

The analysis of the metallographic specimens shows, that after the addition of tungsten, with its content of approx. 16 mass $\%$, The $\mathrm{Al}_{4} \mathrm{C}_{3}$ aluminum carbide was completely replaced by WC tungsten carbides.

No aluminum carbide was found in the tungsten sample either, which shows the effect of the complete replacement of the aluminum carbide with tungsten carbide. Figure 7 presents the morphology of WC carbide precipitates in the alloy and their chemical composition. Moreover, graphite is present in the structure of the obtained high-aluminum cast iron.

According to G. Hägg's rule, this type of formed carbide can be determined, when it depends on the ratio of the radius of the carbon atom $r_{w}$ to the radius of the metal atom $r_{m}$. Thus, according to this rule, carbides can be divided into two types:

- when $\mathrm{r}_{\mathrm{w}} / \mathrm{r}_{\mathrm{m}}<0.59$-straight carbides are formed; this group includes carbides of the $\mathrm{MC}$ type, i.e., $\mathrm{TiC}, \mathrm{NbC}, \mathrm{WC}, \mathrm{VC}, \mathrm{ZrC}$, and the $\mathrm{M}_{2} \mathrm{C}$ type, i.e., $\mathrm{Mo}_{2} \mathrm{C}, \mathrm{W}_{2} \mathrm{C}, \mathrm{Nb}_{2} \mathrm{C}$. If various transition metals appear in the thermodynamic system, the formation of complex carbides can be predicted with high probability. Moreover, in some carbides, not all interstitial spaces are filled with "non-metal" atoms. Then the average chemical composition of these phases' changes and, for example: instead of the MC carbide, the $\mathrm{M}_{4} \mathrm{C}_{3}$ phase, with a deficiency of non-metal atoms may appear in the structure;

- when $r_{\mathrm{w}} / \mathrm{r}_{\mathrm{m}}>0.59$-complex structure iron, chromium, and manganese carbides are formed. The $\mathrm{M}_{3} \mathrm{C}$ type carbide crystallizes in the orthorhombic pattern. On the other hand, the $\mathrm{M}_{23} \mathrm{C}_{6}$ and $\mathrm{M}_{6} \mathrm{C}$ carbides are characterized by a complex cubic lattice, and the $\mathrm{M}_{7} \mathrm{C}_{3}$ carbide crystal lattice is a complex hexagonal lattice (possibly orthogonal and rhombohedral). Good examples of these carbides are: $\mathrm{Fe}_{21} \mathrm{~W}_{2} \mathrm{C}_{6}$ ternary carbides, for the $\mathrm{M}_{6} \mathrm{C}$ type $-\mathrm{W}_{6} \mathrm{C}, \mathrm{Fe}_{3} \mathrm{~W}_{3} \mathrm{C}, \mathrm{Fe}_{4} \mathrm{~W}_{2} \mathrm{C}$ ternary carbides, visible from the EDS tests presented in Figures 8-11. 


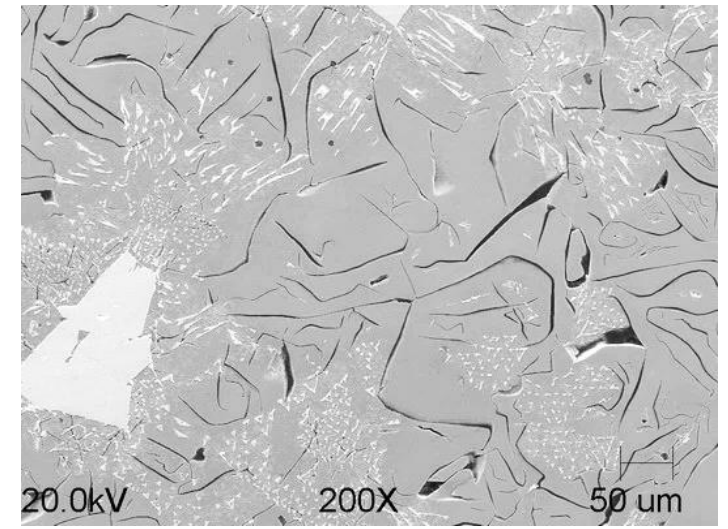

(a)

Chemical composition for area No. 1

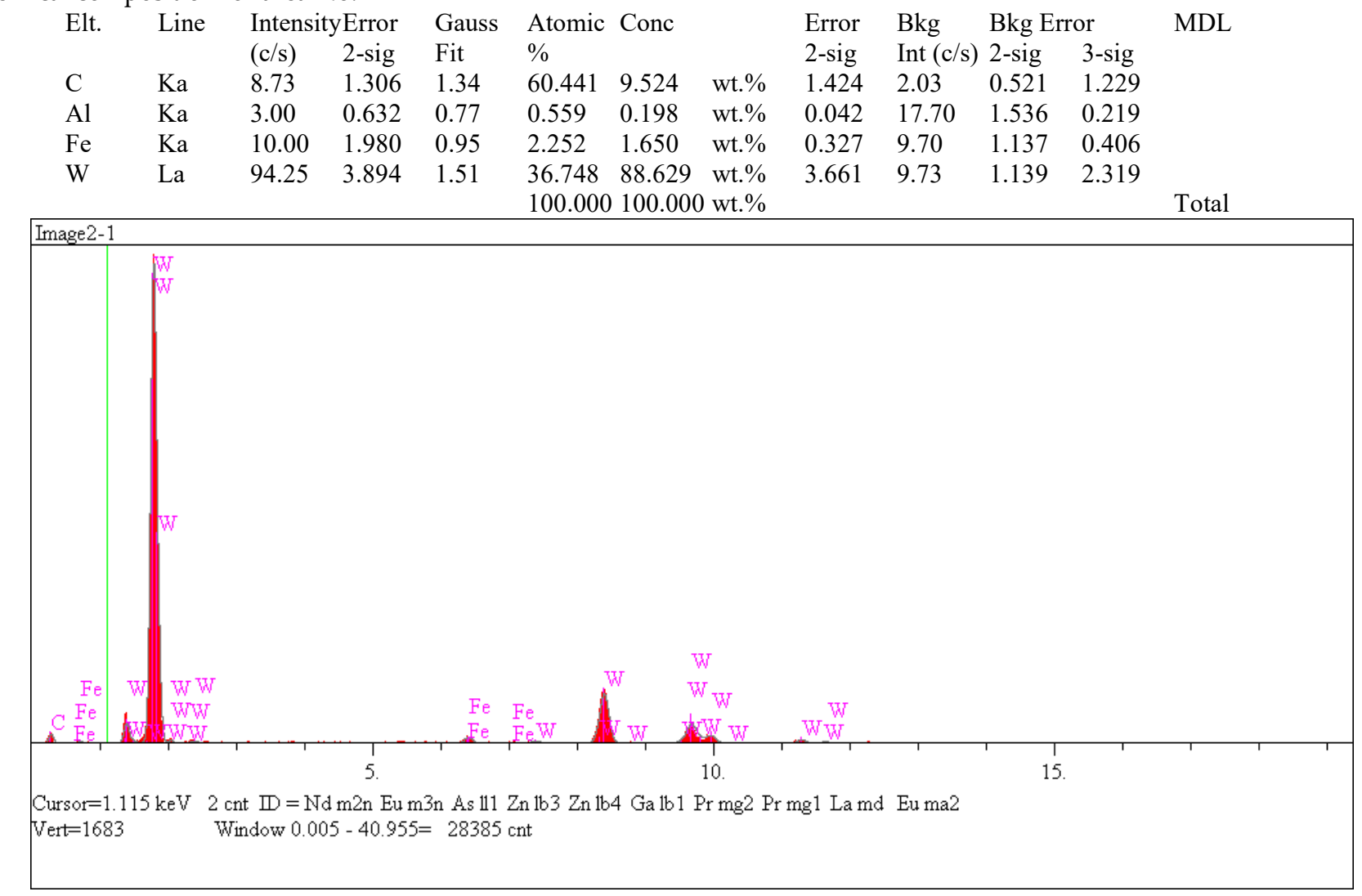

(c)

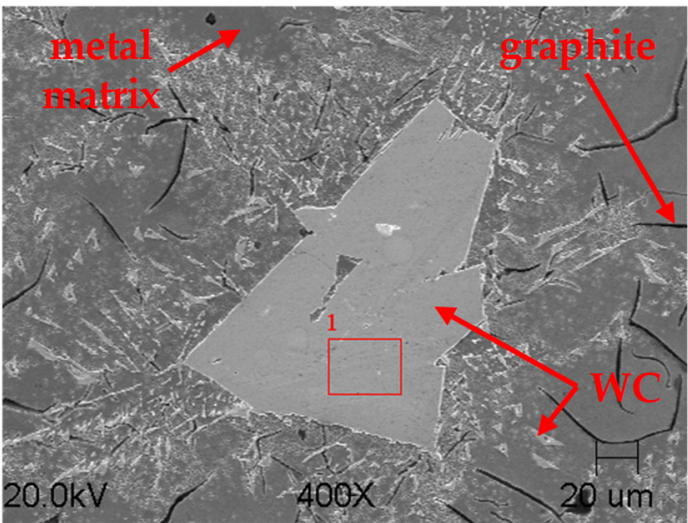

(b)

Error Bkg Bkg Error $\quad$ MDL

2-sig Int (c/s) 2-sig 3-sig

$0.521 \quad 1.229$

$\begin{array}{lll}9.70 & 1.137 & 0.406\end{array}$

$9.73-1.139-2.319$

Total

Figure 8. SEM microstructure of high-aluminum cast iron with the addition of tungsten $(\mathbf{a}, \mathbf{b})$ and EDS X-ray microanalysis of carbide precipitation with a chemical analysis of tungsten carbide (c). 


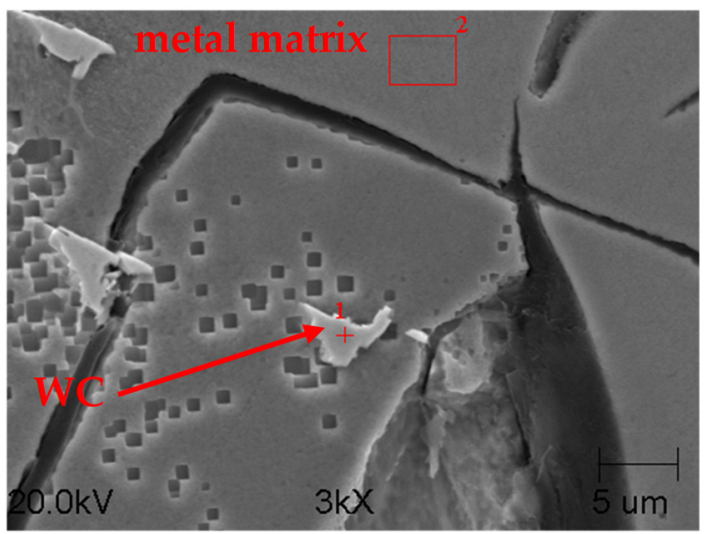

(a)

Chemical composition for point No. 1

\begin{tabular}{|c|c|c|c|c|c|c|c|c|c|c|c|}
\hline \multirow[t]{2}{*}{ Elt. } & \multirow[t]{2}{*}{ Line } & \multicolumn{2}{|c|}{ IntensityError } & \multirow{2}{*}{$\begin{array}{l}\text { Gauss } \\
\text { Fit }\end{array}$} & \multirow{2}{*}{$\begin{array}{l}\text { Atomic } \\
\%\end{array}$} & \multirow{2}{*}{\multicolumn{2}{|c|}{ Conc }} & \multirow{2}{*}{$\begin{array}{l}\text { Error } \\
2 \text {-sig }\end{array}$} & \multirow{2}{*}{$\begin{array}{l}\mathrm{Bkg} \\
\mathrm{Int}(\mathrm{c} / \mathrm{s})\end{array}$} & \multicolumn{2}{|c|}{ Bkg Error } \\
\hline & & $(\mathrm{c} / \mathrm{s})$ & 2-sig & & & & & & & 2-sig & 3-sig \\
\hline $\mathrm{C}$ & $\mathrm{Ka}$ & 24.83 & 1.819 & 1.75 & 77.993 & 21.682 & wt. $\%$ & 1.589 & 2.40 & 0.566 & 1.069 \\
\hline $\mathrm{Al}$ & $\mathrm{Ka}$ & 5.99 & 0.894 & 0.81 & 0.555 & 0.347 & wt. $\%$ & 0.052 & 18.43 & 1.568 & 0.196 \\
\hline $\mathrm{Mn}$ & $\mathrm{Ka}$ & 1.60 & 0.462 & 0.10 & 0.159 & 0.202 & wt. $\%$ & 0.058 & 9.73 & 1.139 & 0.311 \\
\hline $\mathrm{Fe}$ & $\mathrm{Ka}$ & 38.61 & 2.269 & 1.16 & 4.333 & 5.600 & wt. $\%$ & 0.329 & 10.20 & 1.166 & 0.366 \\
\hline W & $\mathrm{La}$ & 85.25 & 3.371 & 1.23 & 16.960 & 72.169 & wt. \% & 2.854 & 9.60 & 1.131 & 2.073 \\
\hline
\end{tabular}

Chemical composition for area No. 2

\begin{tabular}{|c|c|c|c|c|c|c|c|c|c|c|c|c|}
\hline \multirow[t]{2}{*}{ Elt. } & \multirow[t]{2}{*}{ Line } & \multicolumn{2}{|c|}{ IntensityError } & \multirow{2}{*}{$\begin{array}{l}\text { Gauss } \\
\text { Fit }\end{array}$} & \multirow{2}{*}{$\begin{array}{l}\text { Atomic } \\
\%\end{array}$} & \multirow{2}{*}{\multicolumn{2}{|c|}{ Conc }} & \multirow{2}{*}{$\begin{array}{l}\text { Error } \\
\text { 2-sig }\end{array}$} & \multirow{2}{*}{$\begin{array}{l}\mathrm{Bkg} \\
\mathrm{Int}(\mathrm{c} / \mathrm{s})\end{array}$} & \multicolumn{2}{|c|}{ Bkg Error } & \multirow[t]{2}{*}{ MDL } \\
\hline & & $(\mathrm{c} / \mathrm{s})$ & $2-\operatorname{sig}$ & & & & & & & 2 -sig & 3 -sig & \\
\hline $\mathrm{C}$ & $\mathrm{Ka}$ & 1.28 & 0.414 & 1.60 & 10.410 & 2.946 & wt.\% & 0.949 & 1.20 & 0.400 & 1.986 & \\
\hline $\mathrm{Al}$ & $\mathrm{Ka}$ & 161.69 & 4.643 & 3.90 & 32.300 & 20.532 & wt. $\%$ & 0.590 & 6.77 & 0.950 & 0.261 & \\
\hline $\mathrm{Si}$ & $\mathrm{Ka}$ & 7.27 & 0.984 & 0.67 & 1.426 & 0.944 & wt. $\%$ & 0.128 & 6.67 & 0.943 & 0.265 & \\
\hline $\mathrm{Mn}$ & $\mathrm{Ka}$ & 1.64 & 0.467 & 0.11 & 0.153 & 0.198 & wt. $\%$ & 0.056 & 5.53 & 0.859 & 0.224 & \\
\hline $\mathrm{Fe}$ & $\mathrm{Ka}$ & 345.06 & 6.783 & 3.62 & 55.019 & 72.388 & wt.\% & 1.423 & 5.20 & 0.833 & 0.378 & \\
\hline W & $\mathrm{La}$ & 2.17 & 0.538 & 0.19 & 0.691 & 2.993 & wt. $\%$ & 0.742 & 3.67 & 0.699 & 2.087 & \\
\hline & & & & & 100.000 & 100.000 & wt. $\%$ & & & & & Total \\
\hline
\end{tabular}

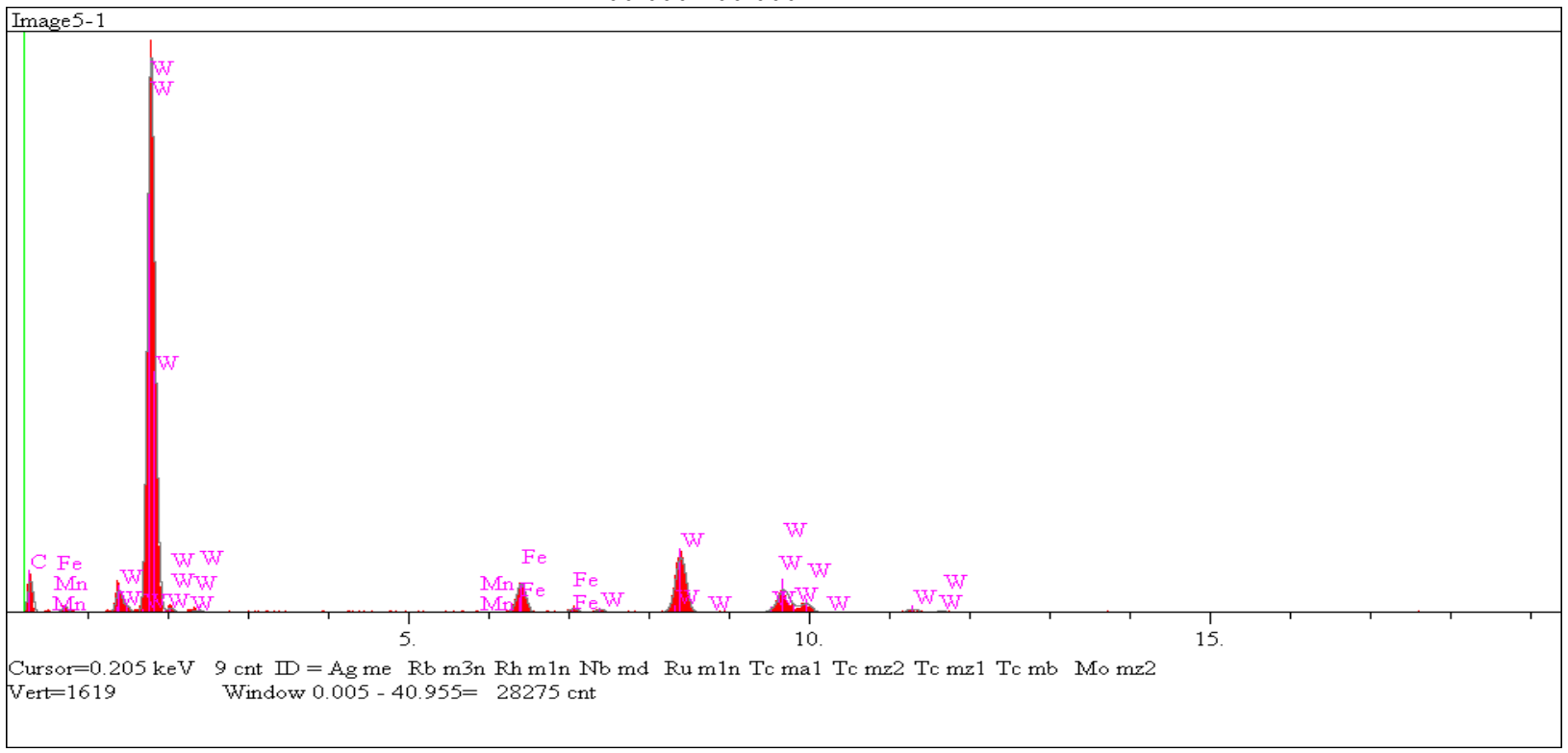

(b)

Figure 9. SEM microstructure (a) of high-aluminum cast iron with the addition of tungsten marking for the chemical composition of the area: no. 1 tungsten carbide, no. 2 metal matrix and graphite in the structure and its EDS X-ray microanalysis (b). 


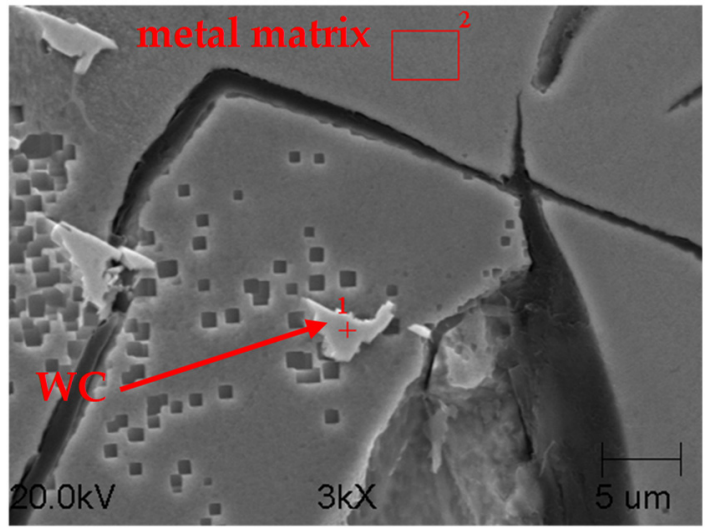

(a)

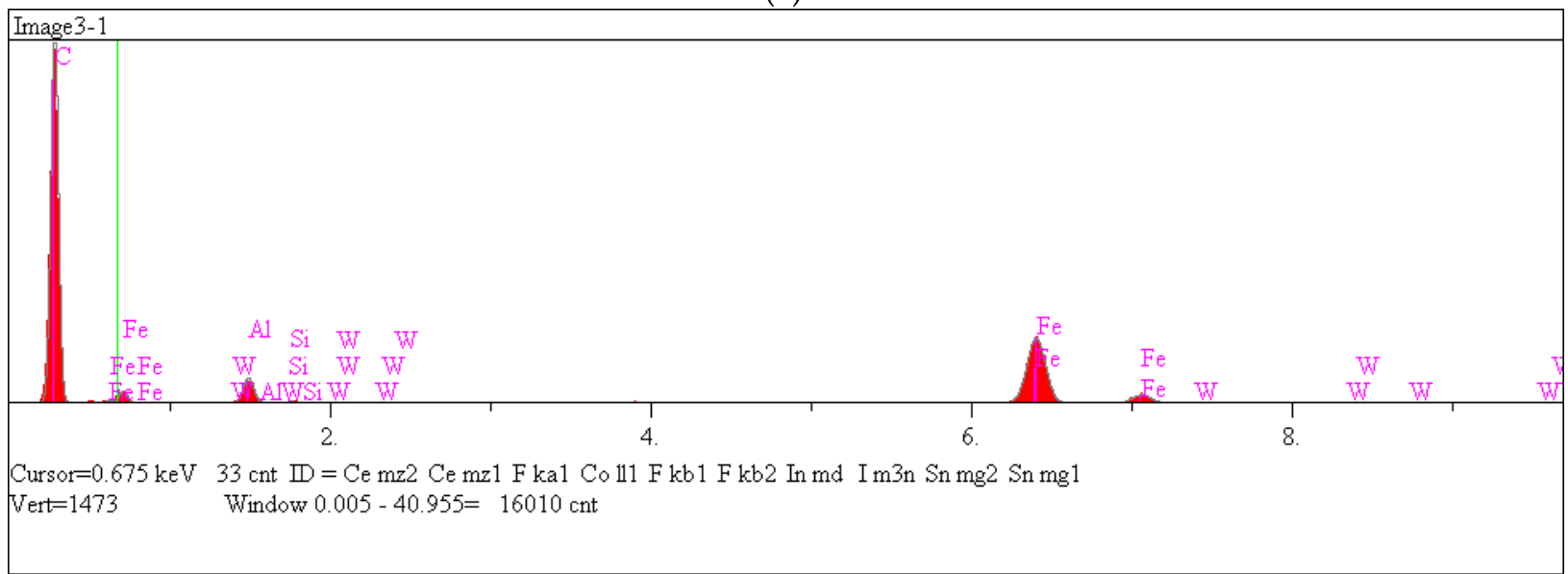

(b)

Figure 10. SEM microstructures of high-aluminum cast iron with the addition of tungsten (a) graphite in the structure and its EDS X-ray microanalysis (b).

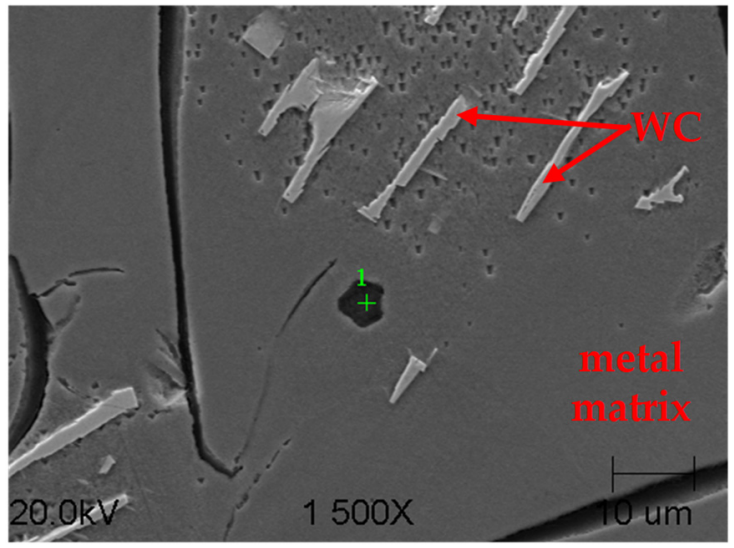

Chemical composition for point No. 1

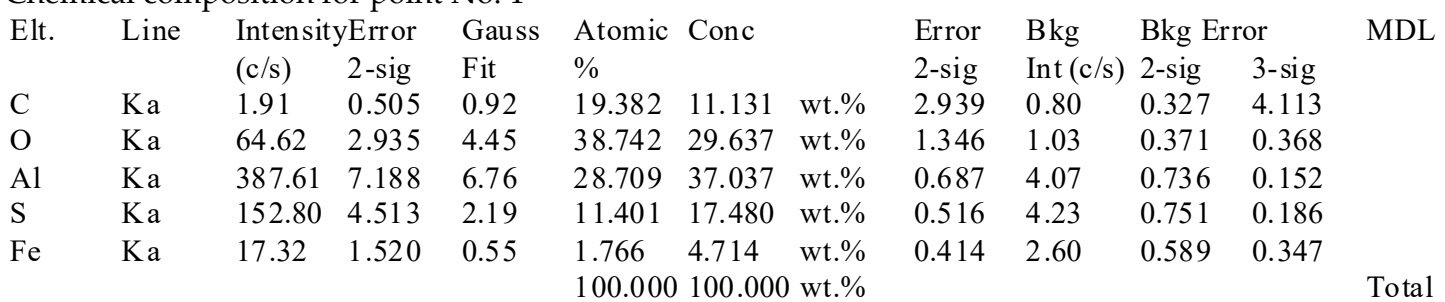

Figure 11. SEM microstructure of high-aluminum cast iron with the addition of tungsten with a chemical composition analysis for no. 1 oxide particle. 
Figure 11 shows the SEM image of samples with a porous metal matrix (the result of etching and preparation of the sample surface). The metal matrix of the alloy ferrite is 20.5 mass \% to 20.7 mass \% aluminum. In addition, the structure includes particles of sulfide and oxide conglomerates with aluminum.

As already mentioned, the presence of graphite was also revealed in the microstructure of the obtained cast iron, which is confirmed by the Fe-Al-C triple system diagram generated by the Thermo-Calc program shown in Figure 2. The fracture of the sample is shiny, fine-grained, and compact. There is also no visible systolic cavity.

Then, an abrasion test was carried out on the Miller machine. The applied test method is used to compare the resistance to abrasion of construction materials of different hardness or materials covered with a layer of ceramic material (e.g., nitrides). The test consists in making at least three attempts, each in not less than $2 \mathrm{~h}$. A 16-h series of 4 four-hour runs is recommended. This makes it possible to determine the wear curve. Figure 12 shows the microstructures after the full abrasion test on the Miller machine.

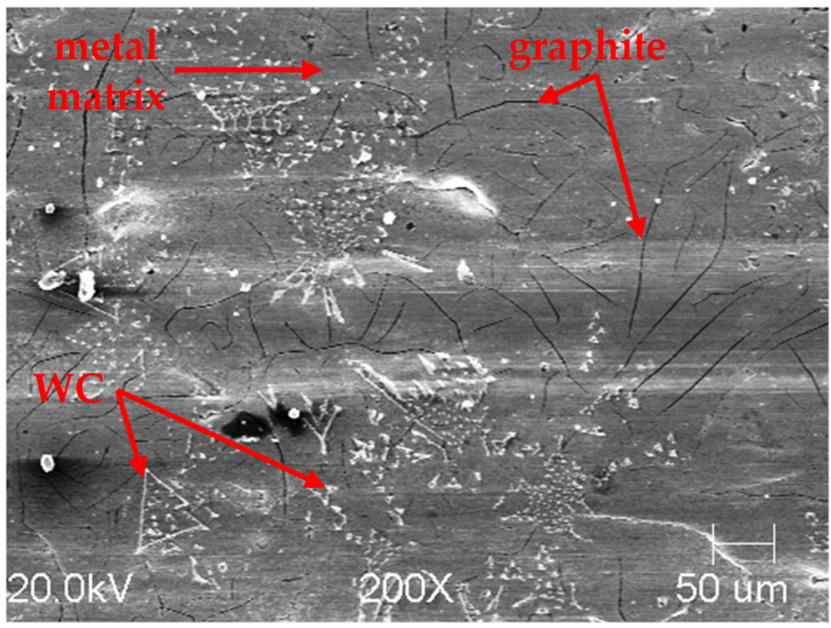

(a)

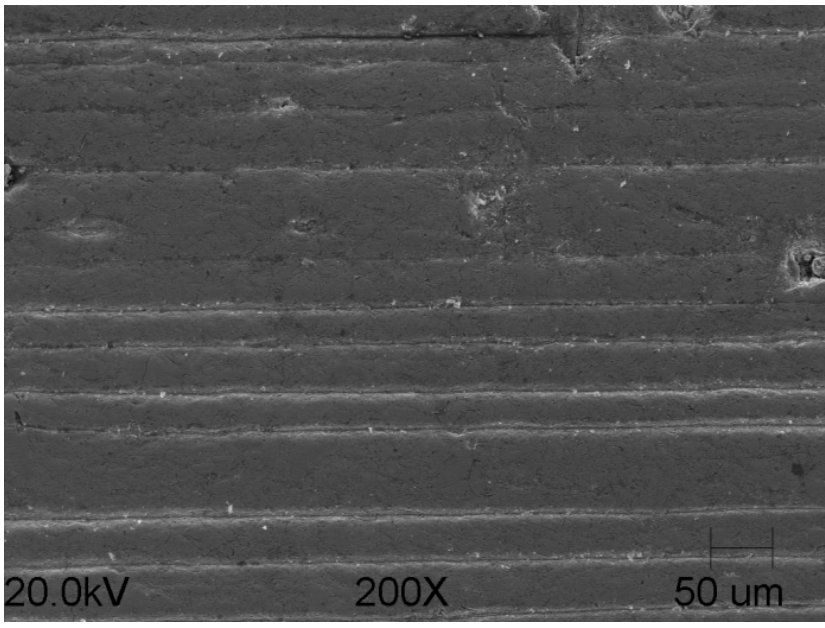

(b)

Figure 12. SEM images of high-aluminum cast iron with the addition of tungsten (a) and SEM images of high-chromium cast iron (b) after a full abrasion test with the Miller machine.

The mass wear rate $\mathrm{V}_{\mathrm{w}}$ was calculated, as determined by the tangent of the angle of inclination of the tangent line to the curve in the second hour of the abrasion wear test [15]:

$$
\mathrm{V}_{\mathrm{W}}=\mathrm{A} \cdot \mathrm{B} \cdot 2^{(\mathrm{B}-1)}
$$

where: A, B - constants determined by the method of least squares.

Table 4 presents the results of abrasion wear tests expressed as a mass loss of the sample.

Table 4. The results of the abrasion wear test.

\begin{tabular}{|c|c|c|c|c|c|c|}
\hline \multirow{2}{*}{ Sample No. } & \multirow{2}{*}{ Starting Weight } & \multicolumn{4}{|c|}{$\begin{array}{c}\text { Weight of the Sample in Grams } \\
\text { after the Time of }\end{array}$} & \multirow{2}{*}{$\mathbf{V}_{\mathbf{w}}$} \\
\hline & & $4 \mathrm{~h}$ & $8 \mathrm{~h}$ & $12 \mathrm{~h}$ & $16 \mathrm{~h}$ & \\
\hline (A) [15] & 19.75 & 19.52 & 19.35 & 19.16 & 18.90 & 0.05537 \\
\hline (B) & 18.22 & 18.12 & 18.05 & 17.97 & 17.89 & 0.02300 \\
\hline (C) [15] & 15.64 & 15.55 & 15.45 & 15.36 & 15.28 & 0.02299 \\
\hline (D) & \multicolumn{6}{|c|}{$\begin{array}{l}\text { No abrasive wear test results were obtained } \\
\text { due to the high slip of the specimen }\end{array}$} \\
\hline
\end{tabular}


Table 4. Cont.

\begin{tabular}{|c|c|c|c|c|c|}
\hline \multirow[t]{2}{*}{ Sample No. } & \multirow{2}{*}{ Starting Weight } & \multicolumn{3}{|c|}{$\begin{array}{l}\text { Weight of the Sample in Grams } \\
\text { after the Time of }\end{array}$} & \multirow{2}{*}{$\mathbf{V}_{\mathbf{w}}$} \\
\hline & & $8 \mathrm{~h}$ & $12 \mathrm{~h}$ & $16 \mathrm{~h}$ & \\
\hline & \multicolumn{5}{|c|}{$\begin{array}{c}\text { Designations [mass } \% \text { ]: (A) High-chromium cast steel }(0.059 \% \mathrm{C}, 25.30 \% \mathrm{Cr}) ;(\mathrm{B}) \\
\text { High-chromium cast iron }(3.35 \% \mathrm{C} \text { and } 21.10 \% \mathrm{Cr}) ;(\mathrm{C}) \mathrm{High}-\text { aluminum cast } \\
\text { iron }(2.12 \% \mathrm{C} \text { and } 30.33 \% \mathrm{Al} \text { and } 6.12 \% \mathrm{~V} \text {, (D) High-aluminum cast iron }(2.12 \% \\
\text { C and } 30.33 \% \mathrm{Al} \text { and } 16.08 \% \mathrm{~W} .\end{array}$} \\
\hline
\end{tabular}

Due to the graphite present in the microstructure in sample (D), acting in this case as a natural lubricant, the test results are not fully reliable, but confirm the high resistance of this material to abrasive wear. Generally, after the test on the Miller machine, no significant wear of the high-aluminum cast iron with the addition of a tungsten sample was found. On the other hand, the surface was well polished, which is clearly shown in Figure 12a. For comparison, the surface appearance of a sample made of chrome cast iron after a full abrasion test with the Miller machine is shown in Figure 12b.

For high-chromium steel (A), the weight loss was the greatest, i.e., $0.85 \mathrm{~g}$ [15]. For chromium cast iron (B) — with the chemical composition [\% mass]: $3.35 \% \mathrm{C} ; 1.5 \% \mathrm{Si} ; 0.63 \%$ $\mathrm{Mn} ; 21.10 \% \mathrm{Cr}$, the weight loss of the sample was $0.33 \mathrm{~g}$ and for sample (C) of high aluminum cast iron with vanadium addition was $0.36 \mathrm{~g}$.

\section{Conclusions}

The conducted experimental studies show that high-aluminum cast iron, despite unfavorable casting properties, is a very interesting construction material that can be used in practice. The conducted research has shown that by appropriate selection of the chemical composition of high-aluminum cast iron, mainly in the field of carbide-forming elements, cast iron with special abrasion resistance properties is obtained.

During this research, a method of counteracting the phenomenon of spontaneous decay was developed, which involves replacing the $\mathrm{Al}_{4} \mathrm{C}_{3}$ carbide with another with the use of a carbide-forming element, which is tungsten. Such treatment not only causes its complete elimination but also changes the shape of the mentioned carbide. In addition, it was shown that the introduction of tungsten into high-aluminum cast iron, leads to a change in thermodynamic conditions and the possibility of the separation of flake graphite in the structure of the tested cast iron, which has a positive effect on the abrasive properties of this material and casting properties.

It should also be noted that during the research it was observed that there is a certain correlation - the more carbides in the metal bath, the higher its viscosity (the case of cast iron with the addition of titanium). Thus, in order to maintain the castability of the molten metal at an appropriate level for proper filling of the mold cavity, the content of carbides in it cannot be arbitrary. The problem practically does not exist in a situation when the element passes into the metal matrix or, as in the case of high-aluminum cast iron with the addition of tungsten, graphite appears next to the carbides.

Author Contributions: R.G.: Conceptualization; Methodology; Investigations; Writing-original draft. D.K.: Conceptualization; Methodology; Project administration; Supervision; Writing-review \&editing. E.G.: Funding acquisition; Writing—review \& editing. A.S.: Investigations; Formal analysis; Investigation; Resources; Visualization. All authors have read and agreed to the published version of the manuscript.

Funding: This research received external funding from project No 5.72.170.684.

Institutional Review Board Statement: Not applicable.

Informed Consent Statement: Not applicable.

Data Availability Statement: Not applicable.

Conflicts of Interest: The author declares no conflict of interest. 


\section{References}

1. Takamori, S.; Osawa, Y.; Halada, K. Aluminum-Alloyed Cast Iron as a Versatile Alloy Materials Transactions. Spec. Issue Environ. Benign Manuf. Mater. Process. Towar. Dematerialization 2002, 2, 311-314.

2. Takamori, S.; Osawa, Y.; Kakisawa, H.; Minagawa, K.; Halada, K. Aluminum alloyed cast iron as an ecomaterial. Mater. Sci. Forum 2003, 426, 3305-3310. [CrossRef]

3. Ten, E.B.; Drokin, A.S. High Aluminum Cast Iron Al22D-Advanced Multifunctional Material. Front. Manuf. Des. Sci. 2011, 121-126, 186-190.

4. Zhumadilova, Z.; Kaldybayeva, S.; Nuruldaeva, G.; Kumar, D. Study of the thermophysical and physical-Mechanical properties of high-alloyed aluminum cast iron. Periódico Tchê Química 2019, 33, 30-40. [CrossRef]

5. Wojtysiak, A. The mechanism of disintegration Fe-Al-C alloy. Metalurgia 1990, 40, 43-61.

6. Wojtysiak, A. A Change in the Mechanical Properties of High-Aluminium Cast Iron during Annealing at High Temperatures. Metalurgia 1990, 41, 81-94.

7. Fraś, E.; Kopyciński, D.; Lopez, H. Processing and properties of high aluminium Fe-Al-C alloys. Int. J. Cast Met. 2002, 15, 9-15. [CrossRef]

8. Kopyciński, D.; Guzik, E.; Szczęsny, A.; Gilewski, R. The structure of high-quality aluminium cast iron. Arch. Foundry Eng. 2012, 12, 53-56. [CrossRef]

9. Falęcki, Z. Odlewnictwo Żeliwa (The Cast Iron Founding); Monograph AGH University of Science and Technology: Kraków, Poland, 1978.

10. Deeki, S.C.; Sikka, V.K. Nikel and iron aluminides: An overview on properties, processing and applications. Intermetalics 1996, 4, 357-375.

11. Rapp, R.A.; Zheng, X. Thermodynamic consideration of grain refinement of aluminium alloys by titanium and carbon. Metall. Trans. 1991, 22, 3071-3075. [CrossRef]

12. Ramirez, B.N.; Schon, C.G. Casting of Iron Aluminides. J. Phase Equilibria Diffus. 2017, 38, 288-297. [CrossRef]

13. Huang, Y.D.; Yang, W.Y.; Sun, Z.Q. Effect of the alloying element chromium on the room temperature ductility of Fe $\mathrm{Al}_{3}$ intermetallics. Intermetallics 2001, 9, 119-124. [CrossRef]

14. Guzik, E.; Kopyciński, D.; Szczęsny, A.; Gilewski, R. Method for Producing High-Aluminium Cast Iron. Patent PL 222671 B1, 31 August 2016.

15. Kopyciński, D.; Guzik, E.; Gilewski, R.; Szczęsny, A.; Dorula, J. Analysis of Structure and Abrasion Resistance of the Metal Composite Based on an Intermetallic FeAl Phase with VC and TiC Precipitates. Arch. Foundry Eng. 2013, 13, 51-54. [CrossRef] 